\title{
Inability to detect significant absorption of immunoreactive soya protein in healthy adults may be relevant to its weak allergenicity
}

\author{
Cecilia M Lund, Christina G Dirks, Mona H Pedersen, Bettina M Jensen and Lars K Poulsen*
}

\begin{abstract}
Soya and peanut are botanically closely related and share cross-reacting antigens, but compared to soya, peanut allergy has a higher prevalence with more severe allergic reactions. Furthermore, the threshold dose for eliciting reactions is higher for soya. A difference in undigested protein absorption between the two foods, might explain this diversity. In the current study the amount of soya protein absorbed after soya bean ingestion in healthy adults was estimated. Ten subjects ingested 100 grams of soya beans (40 grams of soya protein) and blood was drawn before and 1, 3 and 24 hours after administration. Serum was analysed by ELISA and histamine release (HR). In all serum samples the soya protein concentration was below quantification limit $(1.6 \mathrm{ng} / \mathrm{ml}$ which corresponds to $4.8 \mu \mathrm{g}$ or 0.12 parts per million absorbed soya protein.

We could not detect any significant absorption of soya protein. While we cannot totally exlude technical reasons, it may also reflect a true poor absorption in healthy adult volunteers. This could, in turn, be relevant to the apparently weak allergenicity of soy protein by comparison with peanut protein in allergic subjects.
\end{abstract}

Keywords: Soya protein, Food allergen, Absorption, Histamine release

Soya is frequently used as protein enrichment, and the human exposure is therefore as widespread as for peanut. Food allergy to the legumes peanut and soya display, however, quite different prevalence, natural history and severity, in spite of sharing antigenic fractions [1]. Soya generally gives a transient allergy in childhood, with very few anaphylactic and fatal reactions throughout the world whereas peanut allergy causes acute reactions with respiratory problems, skin- and gastrointestinal symptoms [2]. IgE antibodies to both foods are commonly found in individuals clinically reacting to either of them [3]. However, a surprisingly low rate of clinical co-reactivity between peanut and soya is reported. Among 75 peanut-allergic children, none had a history of soya allergy and though $58 \%$ had IgE to soya, only $2 / 22$ patients had a positive oral challenge [4]. This might correlate with the threshold dosages for eliciting a reaction in $1 \%$ of food allergic patients where $2.7 \mathrm{mg}$ peanut but $295 \mathrm{mg}$ soya flour was estimated [5].

\footnotetext{
* Correspondence: cecilia.m.lund@gmail.com; lkpallgy@mail.dk Laboratory of Medical Allergology, Allergy Clinic, Copenhagen University Hospital, Gentofte, Department 22, Niels Andersen Vej 65, DK-2900, Hellerup, Denmark
}

(c) 2013 Lund et al.; licensee BioMed Central Ltd. This is an Open Access article distributed under the terms of the Creative Commons Attribution License (http://creativecommons.org/licenses/by/2.0), which permits unrestricted use, distribution, and reproduction in any medium, provided the original work is properly cited.
These highly varying thresholds could reflect differences in absorption or distribution of the two proteins. We have previously investigated the absorption of peanut [6], where 17 non-allergic subjects ingested 5-100 $\mathrm{g}$ of peanuts. Immunoreactive peanut protein in serum, were determined by ELISA and histamine release (HR) and compatible kinetics were found with protein being detectible 10-30 $\mathrm{min}$ after ingestion and peaking at 2-3 hours. No such investigations have been performed for soya protein.

We aimed to determine the absorption of soya, i.e. immunoreactive and potentially allergenic protein in serum of healthy adults after ingesting soya beans. Raw soya beans were considered to be uneatable and accordingly a meal of cooked soya beans was considered the optimal source of intact soya allergens.

\section{Findings}

\section{Materials and methods}

Ten subjects (aged 21-28, 5 females) without history of any type of allergy, atopic dermatitis, rhinitis, or asthma were included. Pregnancy, daily medication (except birth- 
control) and significant concurrent disease were exclusion criteria. Absence of allergy was confirmed by a negative blood screening for peanut and soya bean IgE (Phadia, Uppsala, Sweden) and a negative skin prick test, performed in accordance with guidelines from European Academy of Allergy and Clinical Immunogy. In the skin prick test, the subjects were tested with the standard panel of inhalant allergens (ALK-Abello Hørsholm, Denmark), soya bean (cooked, raw and powder) and peanut prickprick tests. The study was approved by the local ethical committee (j. nr. KF 01-081/01).

In a single dose soya bean challenge the subjects were given $100 \mathrm{~g}$ of dry soya beans, i.e. $40 \mathrm{~g}$ of protein. The ecological soya beans with a declared content of $40 \%$ of protein, $27 \%$ of carbohydrates and $18 \%$ of fat, soaked in water for 16 hours at $5^{\circ} \mathrm{C}$ and were then boiled in water for 60 minutes. The soya beans were served in a canned tomato sauce with garlic, basil, 1 tsp sugar and salt. After abstaining for 24 hours from soya products and 8 hours of fasting, the meal was ingested. Blood samples were drawn before and 1, 3 and 24 hours after the beginning of the meal. Serum was collected and stored at $-20^{\circ} \mathrm{C}$.

The soya protein ELISA was a direct sandwich assay employing rabbit anti-soya antibodies against an aqueous extract of unprocessed soya beans [7]. The standard curve was performed with the same extract $(0.8 \mathrm{ng} / \mathrm{ml}$ $600 \mathrm{ng} / \mathrm{ml}$ ) (protein determined by amino acid analysis), and the limit of detection was determined as the background $+3 \times$ S.D. (Figure 1).

For determination of soya allergens by histamine release technique, human basophils in peripheral blood mononuclear cells were passively sensitized with soya specific IgE (serum from severe soya allergic) or nonspecific IgE (serum from healthy control) [7]. Cells were challenged ( 1 hour) with serum (20\% final concentration) from the 10 subjects. A standard curve $(25 \mathrm{pg} / \mathrm{ml}-$ $80 \mathrm{ng} / \mathrm{ml}$ ) was made with soya bean extract (Greer, NC, USA) in 20\% control serum. Supernatant was analysed fluorometrically for histamine using glass fiber coated micro titer plates as described in Stahl Skov et al [8]. Results are expressed as percentage of total cellular histamine content (\% HR).

\section{Results}

Using the soya protein ELISA, which was done in duplicate, we could only repeatedly detect a weak signal in a single sample (subject F, 24 h) (Figure 2), having an OD 0.06 (0 ng $+3 \times \mathrm{SD}=0.023)$. Using $\mathrm{HR}$, which also was performed in duplicate, a significant response was again observed with the same sample, however with a concentration below the last point of the standard curve. Accordingly the concentration of soya protein was estimated as $<1.6 \mathrm{ng} / \mathrm{ml}$ (ELISA, $1+1$ dilution) and $<25 \mathrm{pg} / \mathrm{ml}$ (HR).

\section{Discussion}

Using two different assays, of which one was known to identify whole intact proteins [7] and the other based on IgE and thus detecting allergens, we could only marginally detect soya protein in one serum sample ( 24 hour). There were only 10 subjects in this study. But since our results were uniformly negative for all 10 subjects, (in addition to 3 pilot subjects treated with different doses) we do not think that adding more subjects would substantially change the conclusions.

Low soya absorption could be caused by low protein dose or destruction during processing or digestion. In a pilot project 3 subjects were served $150 \mathrm{~g}$ of soya beans, but all were unable to eat more than a $100 \mathrm{~g}$, which also was the highest intake in the peanut study. Since the general protein content of peanut is about $25 \%$ compared to $40 \%$ in soya bean, the ingested amount of protein is higher in this study. Furthermore, soya beans were cooked for 60 minutes to make them eatable, however, this treatment is found not to change IgE and IgG epitopes [9].

Some proteins are known to be rapidly degraded at $\mathrm{pH}$ 2.0, imitating gastric acid [10]. There are no such human data for soya protein, but studies in pigs suggest that the major storeage protein glycinin and conglycining, which are important allergens in humans, [11] maintain some immunogenicity after passing the stomach [12].

In our peanut absorption study [6], protein concentrations varied between 4-15 $\mathrm{ng} / \mathrm{ml}$, with a peak after 23 hours and detectable peanut protein after $24 \mathrm{~h}$.

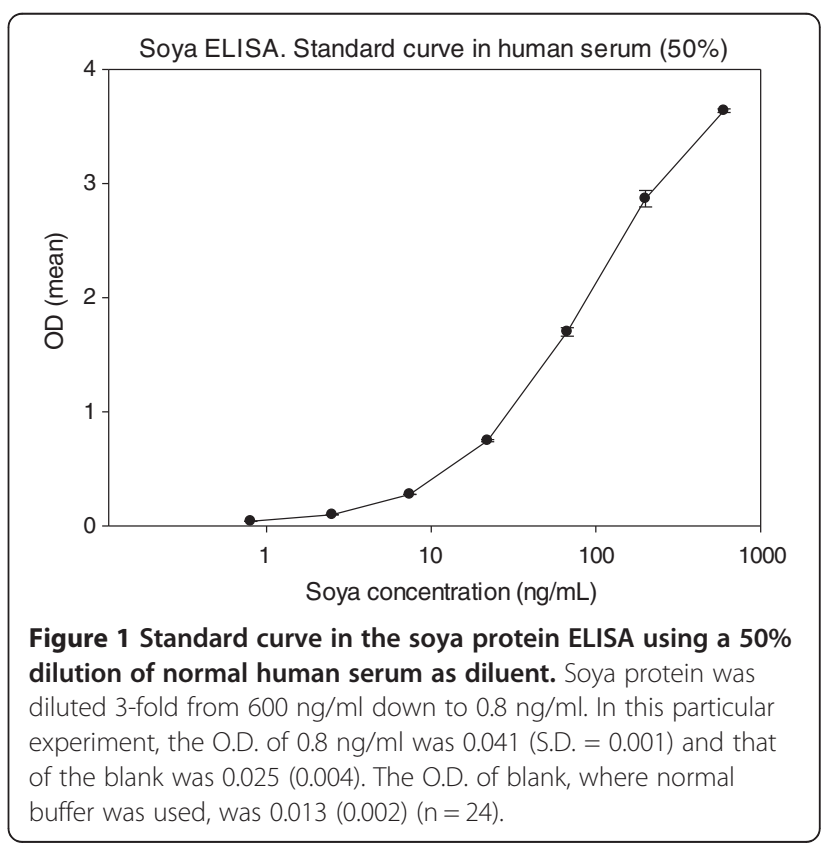



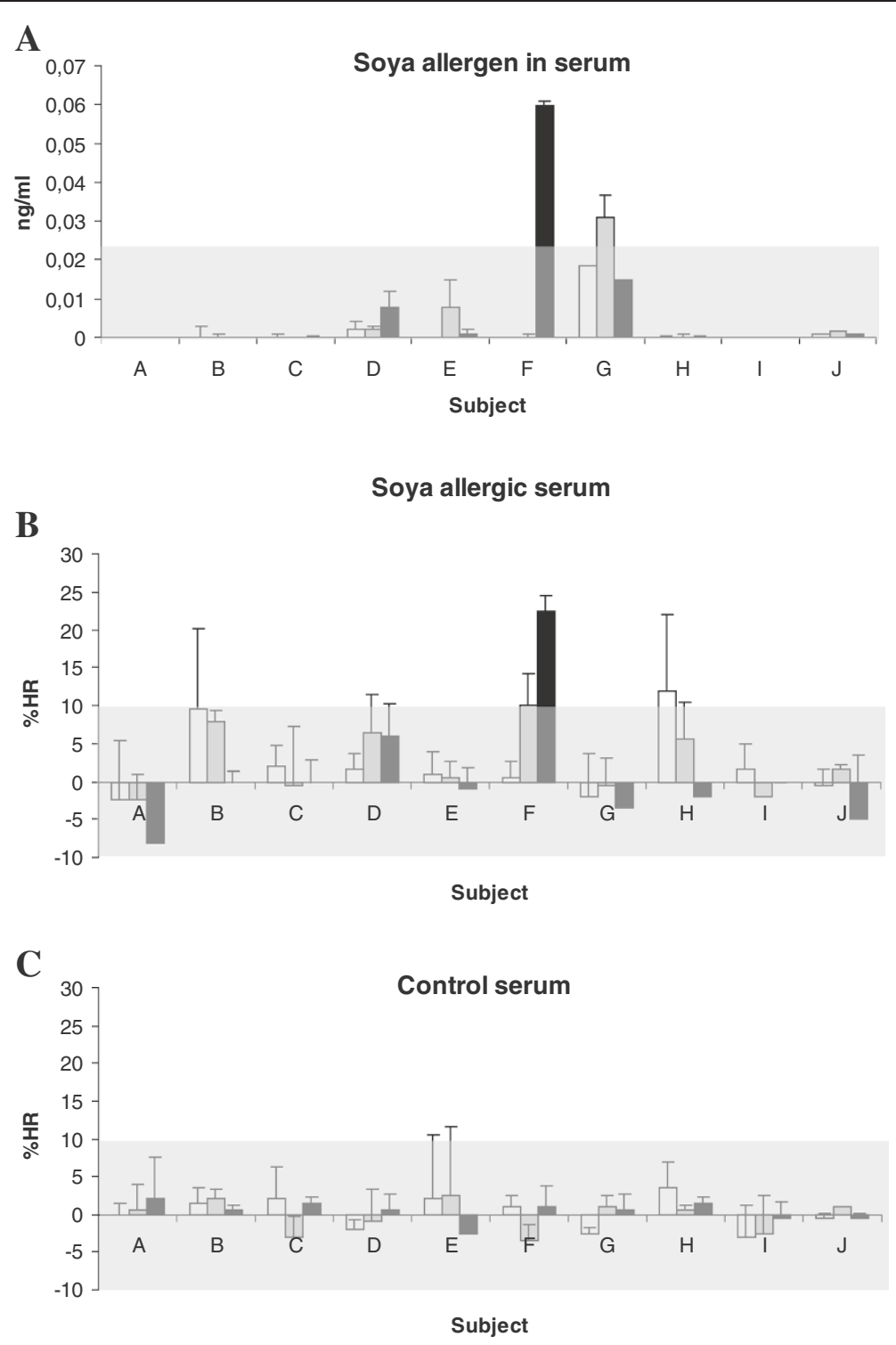

Figure 2 Detection of soya allergen in serum from soya challenged subjects. A) Serum samples (0, 1, 3 and 24 hour after ingestion of soya meal) were analyzed by ELISA. Results were corrected from background (0 hour serum sample) and samples with an

$\mathrm{OD}>0.023 \mathrm{ng} / \mathrm{ml}$ (mean $+3 \times \mathrm{SD}, 0$ h samples) were considered positive for soya. Gray zone indicate cut off value. B) Human basophils $(\mathrm{n}=2$ donors) sensitized with IgE from soya allergic or healthy control were stimulated with serum from the challenged subjects $(0,1,3$ and 24 hour after ingestion of soya meal). Results (\% released histamine,\%HR) were corrected from background ( 0 hour serum sample) and samples with $a \% H R>9.3 \%$ (mean $+3 \times S D$, control serum) were considered positive for soya. Gray zones indicate cut off value. White square: 1 hour, Gray square: 3 hour, Black square: 24 hour.

However, absorbed protein showed a considerably interindividual variation. Both studies were performed on healthy adults, and it would be interesting to investigate if there is a difference in absorption of proteins in healthy persons compared to allergic patients. Husby et al. [13] observed concentrations of $10.5 \mathrm{ng} / \mathrm{ml}$ ovalbumin in blood, 3 hours after ingestion of $3 \mathrm{~g}$ of ovalbumin. Castell et al. [14] found protein concentrations of 2000-10000 pg in blood $48 \mathrm{~h}$ after ingestion of bromelain, $4 \mathrm{~g} / \mathrm{day}$. The absorption described in these three studies plus our own peanut study is far higher than in the present soya study, where the absolute amount in plasma was below $4.8 \mu \mathrm{g}$ or 0.12 parts per million (ppm) of the $40 \mathrm{~g}$ of soya protein consumed.

These results support our theory of soya being a poorly absorbed protein, which may explain its moderate allergenicity in comparison with the high allergenicity of peanut. 


\section{Abbreviations}

HR: Histamine release.

\section{Competing interests}

The authors have no competing interests.

\section{Authors' contributions}

CML carried out the clinical study, recruitment of study population, data acquisition and analysis, designed the case report forms and drafted the manuscript. BMJ was responsible for the conduction of the histamine release test, MHP was responsible for the conduction of the ELISA measurements. CGD participated in coordination of the clinical study and manuscript revising. LKP designed the study, wrote the protocol and participated in data analysis and manuscript revising. All authors have read and approved the final manuscript.

Received: 10 October 2012 Accepted: 20 January 2013

Published: 4 February 2013

\section{References}

1. Eigenmann PA, Burks AW, Bannon GA, Sampson HA: Identification of unique peanut and soy allergens in sera adsorbed with cross-reacting antibodies. J Clin Immunol 1996, 98:969-978.

2. Sicherer SH, Sampson HA, Burks AW: Peanut and soy allergy: a clinical and therapeutical dilemma. Allergy 2000, 55:515-521.

3. Barnett D, Bonhamn B, Howden ME: Allergenic cross reactions among legume foods- an in vitro study. J Allergy Clin Immunol 1987, 79:433-438.

4. Jensen LB, Andersen M, Skov PS, Poulsen LK, Bindeslev-Jensen C: Risk assesment of clinical reactions to legumes in peanut-allergic children. WAO J 2008, 10(1):162-167.

5. Bindslev-Jensen C, Briggs D, Osterballe M: Hypothesis paper. Can we determine a treshold level for allergenic foods by statistical analysis of published data in the litterature? Allergy 2002, 57:741-746.

6. Dirks CG, Pedersen MH, Plazter MH, Bindeslev-Jensen C, Skov PS, Poulsen LK: Does absorption across the buccal mucosa explain early onset of foodinduces allergic systemic reactions? J Allergy Clin Immunol 2005, 115(6):1321-1323.

7. Pedersen MH, Holzhauser T, Bisson C, Conti A, Jensen LB, Skov PS, BindslevJensen C, Brinch DS, Poulsen LK: Soybean allergen detection methods- a comparison study. Mol Nutr Food Res 2008, 52:1486-1496.

8. Stahl PS, Norn S, Weeke B: A new method for detecting histamine release. Agents Actions 1984, 14:414-416.

9. Burks AW, Williams LW, Thresher W, Connaughton C, Cockrell G, Helm RM: Allergenicity of peanut and soybean extracts altered by chemical and thermal denaturation in patients with atopic dermatitis and positive food challenge. J Allergy Clin Immunol 1992, 90:889-897.

10. Untersmayr $E$, Schöll I: Antacid medication inhibits digestion of dietary proteins and causes food allergy: a fish allergy model in BALB/c mice. J Allergy Clin Immunol 2003, 112(3):616-623.

11. Holzhauser T, Wackermann O, Ballmer-Weber BK, Bindslev-Jensen C, Scibilia J, Perono-Garoffo L, Utsumi S, Poulsen LK, Vieths S: Soybean (Glycine max L.) allergy in Europe: Glycinin and $\beta$-conglycinin are potential diagnostic markers for severe allergic reactions to soy. J Allergy Clin Immunol 2009, 123(2):452-458.

12. Zhao Y, Qin G, Sun Z, Zhang X, Bao N, Wang T, Zhang B, Zhang B, Zhu D, Sun L: Disappearance of immunoreactivw glycinin and beta-conglycinin in the digestive tract of piglets. Archives Of Animal Nutrition 2008, 62(4):322-330.

13. Husby S, Jensenius JC, Svehag SE: Passage of undegraded dietary antigen into the blood of healthy adults. Quantification, estimation of the size distribution, and relation of the uptake to levels of specific antibodies. Scand I Immunol 1985, 22:83-92.

14. Castell JV, Friedrich G, Kuhn CS, Poppe GE: Intestinal absorption of undegraded protein in men: presence of bromelain in plasma after intake. Am J Physiol 1997, 273:G139-G146.

doi:10.1186/2045-7022-3-6

Cite this article as: Lund et al:: Inability to detect significant absorption of immunoreactive soya protein in healthy adults may be relevant to its weak allergenicity. Clinical and Translational Allergy 2013 3:6.

\section{Submit your next manuscript to BioMed Central and take full advantage of:}

- Convenient online submission

- Thorough peer review

- No space constraints or color figure charges

- Immediate publication on acceptance

- Inclusion in PubMed, CAS, Scopus and Google Scholar

- Research which is freely available for redistribution 